\title{
Stability of fruit bases and chocolate fillings
}

\author{
Estabilidade de bases de frutas e recheios para chocolates
}

\section{Joice Natali MIQUELIM ${ }^{1}$, Maria Regina ALCÂNTARA², Suzana Caetano da Silva LANNES ${ }^{1 \star}$}

\begin{abstract}
Syrups with high sugar content and dehydrated fruits in its composition can be added to chocolate fillings to reduce the need of artificial flavor and dyes attributing a natural appeal to the product. Fruit bases were produced with lyophilized strawberry, passion fruit, and sliced orange peel. Rheological dynamic oscillatory tests were applied to determine the products stability and tendency of shelf life. Values of $\mathrm{G}^{\prime}<\mathrm{G}^{\prime \prime}$ were observed for strawberry and passion fruit flavor, whereas values of $\mathrm{G}^{\prime}>\mathrm{G}^{\prime \prime}$ were found for orange flavor during the 90 days of storage. It was observed that shear stress values did not vary significantly suggesting product stability during the studied period. For all fillings, it was found a behavior similar to the fruit base indicating that it has great influence on the filling behavior and its stability. The use of a sugar matrix in fillings provided good shelf life for the fruit base, which could be kept under room temperature conditions for a period as long as one year. The good stability and storage conditions allow the use of fruit base for handmade products as well as for industrialized products. Keywords: chocolate; fillings; stability; shelf life; rheology.
\end{abstract}

\section{Resumo}

Xaropes com alto conteúdo de açúcar e frutas desidratadas podem ser adicionados a recheios de produtos de chocolate a fim de reduzir a necessidade da adição de aromas e corantes, atribuindo um apelo natural ao produto. Foram produzidas bases de frutas e recheios com morango e maracujá liofilizados e casca de laranja in natura. Testes reológicos de oscilação foram usados para determinar a estabilidade do produto e tendência de vida de prateleira. Valores de $G^{\prime}<G^{\prime \prime}$ foram observados para as bases de morango e maracujá, enquanto para a de laranja obtiveram-se valores $\mathrm{G}^{\prime}>\mathrm{G}^{\prime \prime}$ durante 90 dias de armazenamento. Observou-se que valores de tensão de cisalhamento não variaram significantemente, sugerindo a estabilidade dos produtos durante o período estudado. Para todos os recheios, foi obtido comportamento semelhante ao das bases, indicando que estas estabelecem grande influência no comportamento e estabilidade dos recheios. O uso da matriz de açúcar colaborou com um prolongamento da vida de prateleira da base de fruta, que conseguiu manter o produto final armazenado em temperatura ambiente por período acima de um ano. A boa estabilidade e condições de armazenamento permitem o uso das bases de frutas em produções artesanais e industriais.

Palavras-chave: chocolate; recheios; estabilidade; vida de prateleira; reologia.

\section{Introduction}

Many kinds of fillings are used in chocolate products, such as creams, liquorices, fondants, jellies, and dried fruits base into the chocolate mass. The fruits can be crystallized, covered by chocolate, and used as jellies or as creamy fillings (PERESSINI et al., 2000; RICHMOND, 2002; RICHMOND, 2004).

Fruit jellies are made of fruit pulp, water, sugar and gums at less $0.3 \%$ of the filling total weight (LENNOX, 2002; RICHTER; LANNES, 2007). The fruit pulp can be used fresh or dehydrated giving lower water activity for the final product and a better shelf life (RICHMOND, 2002). Xanthan gum, when at concentration below $0.3 \%$, increases filling viscosity. Concentrations higher than this value lead to sugar interactions affecting some of its properties (CORNILLON; SALIM, 2000; LIZARRAGA et al., 2006; RICHTER; LANNES, 2007).

Sucrose is the major ingredient of fillings; corn syrup and inverted sugar are other kinds of sugar used. The use of inverted sugar and corn syrup prevent crystallization, regarding the sucrose hydrophilic characteristic, helping the formation of a homogeneous phase (ASHURST, 1999; OURIEV; URIEV, 2005; MIQUELIM; BEHRENS; LANNES, 2008). Fondant sugar can be added to the jelly base providing creaminess (NEBESNY et al., 2005).

The viscoelastic properties such as G' (storage modulus) and G" (loss modulus) could be obtained through oscillatory tests using a frequency variation between 0.1 and $10 \mathrm{~Hz}$ (ADAMS; FRITH; STOKES, 2004; MINIFIE, 1983). Rotational test allows the characterization trough tension and viscosity curves showing its behavior when the material is submitted to a controlled shear rate. In this case, is possible to observe how viscosity varies when under stress (ADAMS; FRITH; STOKES, 2004; MUNIZAGA-TABILO; BARBOSA-CANOVAS, 2005). The rotational test previews the fluid behavior for complex systems such as extrusion, mixers, and dozers (RAO, 1999). 
This study aimed to characterize fruit base and fondant base fillings determining their stability and behavior during the storage period. Analysis of how the fruit base influences the filling according to the particles size of the fruits used, as well its stability during storage period was performed through a rheological study.

\section{Materials and methods}

\subsection{Materials}

Six formulations were developed (three fruit bases and three fondant fillings bases); both the fruit bases and fondant bases were produced with strawberry, passion fruit, and orange fruit bases. Sugar, inverted sugar, glucose syrup, citric acid, and xanthan gum were obtained from local market of confectionary product distributors. Strawberry and passion fruit were obtained by lyophilizatio and orange slices.

\section{Fruit bases}

For the strawberry and passion fruit bases, inverted sugar, corn syrup, and water were mixed in this sequence at the proportion of 1:1:1 and heated up to temperature of $105^{\circ} \mathrm{C}$ creating a sugar syrup for the mix. The dehydrated fruit was added followed by a preservative and dye.

For the orange bases, water was added to the inverted sugar and corn syrup at the proportion 1:1:2. After the addition of the orange slices, it was boiled until the ring vitrification (the white part inside the ring starts to become transparent). Since the long boiling time could lead to decomposition of orange citric acid raising the $\mathrm{pH}$, the addition of citric acid to the formulation was necessary to adequate the fruit base to $\mathrm{pH} 4$.

\section{Fondant filling}

Fondant was melted with $30 \%$ wt of hot water, and next the fruit bases was added and the filling was homogenized with $0.3 \%$ wt of xanthan gum. The addition of xanthan gum is easier when mixed with sucrose,avoiding agglomeration. A Kitchen Aid mixer was used. A non correct dispersion of the gum would cause a wrong gel formation avoiding sustaining the stability and viscosity of the product (FERNANDEZ et al., 2007; ROBERTS; BARNES; CAREW, 2001).

The choice of fondant sugar as the raw material was made because it is a versatile product with large application in the confectionery industry. The low cost and high soluble solids content, which can minimize microbial contamination, influenced the choice. The addition of dye and flavor to the final formulation of fondant filling was not necessary.

\subsection{Methods}

\section{Water activity}

Data were obtained for the fillings after their elaboration and after 30,60, and 90 days of storage. NOVASINA-AW equipment was used for determinations at $25^{\circ} \mathrm{C}$.

\section{Solid content}

The determination was performed only for the fruit bases in a Shibuya refractometer and results presented in ${ }^{\circ}$ Brix.

\section{Rheology}

The rheological determinations were done for the three types of fruit bases and fillings. The tests were performed in a plate rheometer with rotational and oscillatory measurements, model MCR 300 - Paar Physica with a Peltier plate for temperature control at $25^{\circ} \mathrm{C}$ and a plate with $\varnothing 50 \mathrm{~mm}$ (PP 50). A gap of $1 \mathrm{~mm}$ was used for the passion fruit flavor tests in both formulations fruit bases and fondant filling. For the strawberry flavor tests, the gap was of 2 and $2.5 \mathrm{~mm}$ for the orange flavor tests in both samples.

The oscillatory test was performed using a frequency sweep varying the frequency from 0.01 to $10 \mathrm{~Hz}$, with controlled stress of $0.01 \mathrm{~Pa}$ acquiring data in intervals of 30 seconds in order to obtain the values of $\mathrm{G}^{\prime}$ (storage) and $\mathrm{G}^{\prime \prime}$ (loss) moduli. The Rotational test was conducted varying shear rate from $0.01 /$ second to $1000 /$ second in order to characterize the flow behavior, i.e.

To obtain the flow curves behavior of the fruit bases during the 90 days of storage. The tests were performed in triplicate and the curves presented represent the means obtained.

\section{Results and discussion}

\subsection{Water activity (Aw) and solid content}

Water activity is a way to determine the availability of free water for microbial growth in foods. The water availability together with other factors such as $\mathrm{pH}$ and product composition has major influence on its microbial stability. High sugar content, higher than $65^{\circ} \mathrm{Brix}$ (TORREY, 1974), inhibit, as well, microbial growth and provide products with intermediate levels of water activity due to the solid content (LEITÃO, 1987).

The results presented in Table 1 were submitted to ANOVA. No significant difference was found $(\mathrm{p}<0.05)$ during storage for the fillings, which leads to the conclusion that the product remains stable during the studied period. In general, there is a slightly decrease in the values during the 90 days evaluated, but this did not influence the characteristics of the products.

Table 1. Water activity during storage with correspondent media for the fruit fillings.

\begin{tabular}{lccc}
\hline Filling/time (days) & \multicolumn{3}{c}{ Water activity } \\
\cline { 2 - 4 } & Strawberry & Passion fruit & Orange \\
\hline 0 & 0.761 & 0.768 & 0.761 \\
30 & 0.761 & 0.766 & 0.764 \\
60 & 0.749 & 0.54 & 0.753 \\
90 & 0.743 & 0.757 & 0.755 \\
Media* $^{*}$ & $0.7535^{\mathrm{a}}$ & $0.7612^{\mathrm{a}}$ & $0.7582^{\mathrm{a}}$ \\
\hline
\end{tabular}

${ }^{*}$ means with the same letters are not significantly different from each other at the $5 \%$ level of significance. 
The loss of water could be related with water loss to the environment in order to reach product equilibrium, causing, in some cases, sugar crystallization (CORNILLON; SALIM, 2000).

The data obtained are presented in Table 2. All fruit bases showed Brix values higher than $65^{\circ}$ indicating a good shelf life to the product at room temperature (TORREY, 1974).

\subsection{Rheology}

Figures 1 and 2 illustrate the rheological behavior for the three types of fruits and fondant fillings, respectively.

For the passion fruit bases (Figure 1), it was possible to observe the storage modulus $\left(\mathrm{G}^{\prime}\right)<$ loss modulus $\left(\mathrm{G}^{\prime \prime}\right)$ characterizing a typical viscous behavior during observation. The yield stress of this period presented no significantly changes

Table 2. Soluble solids for the fruit mixes.

\begin{tabular}{cccc}
\hline & \multicolumn{3}{c}{ Fruit mix } \\
\cline { 2 - 4 } & Strawberry & Passion fruit & Orange \\
\hline${ }^{\circ}$ Brix & 68 & 69 & 73 \\
\hline
\end{tabular}

indicating good product stability (Table 1). The passion fruit bases presented frequency dependence of $G^{\prime}$ and $G$ ", where G'< G' (parallel curves). This is a like-gel behavior (GOETZ; BALZER; HINRICHS, 2005). According to Rao (MUNIZAGATABILO, BARBOSA-CANOVAS, 2005), in weak gels there is a dependency of frequency due to relaxation process inside the product presenting a small magnitude difference between $G^{\prime}$ and G" moduli.

The behavior obtained for the strawberry fruit bases was different from that of the passion fruit. Strawberry and orange are fruits of variable hemicellulose content (pectin and other gums) that affected the results and would help understand the findings. The values of $\mathrm{G}^{\prime}$ and $\mathrm{G}^{\prime \prime}$ ' were closer and an inversion of points was observed for frequencies higher than $1 \mathrm{~Hz}$. Structural modifications can occur at frequencies higher than $1 \mathrm{~Hz}$, as shown by the inversion of the moduli. This behavior can suggest some difficulties by dealing with the product during manufacturing.

For the orange fruit bases, the test was conducted six times to minimize the error due to the variation of particle size. The curves (Figure 1) correspond to the average results. The orange
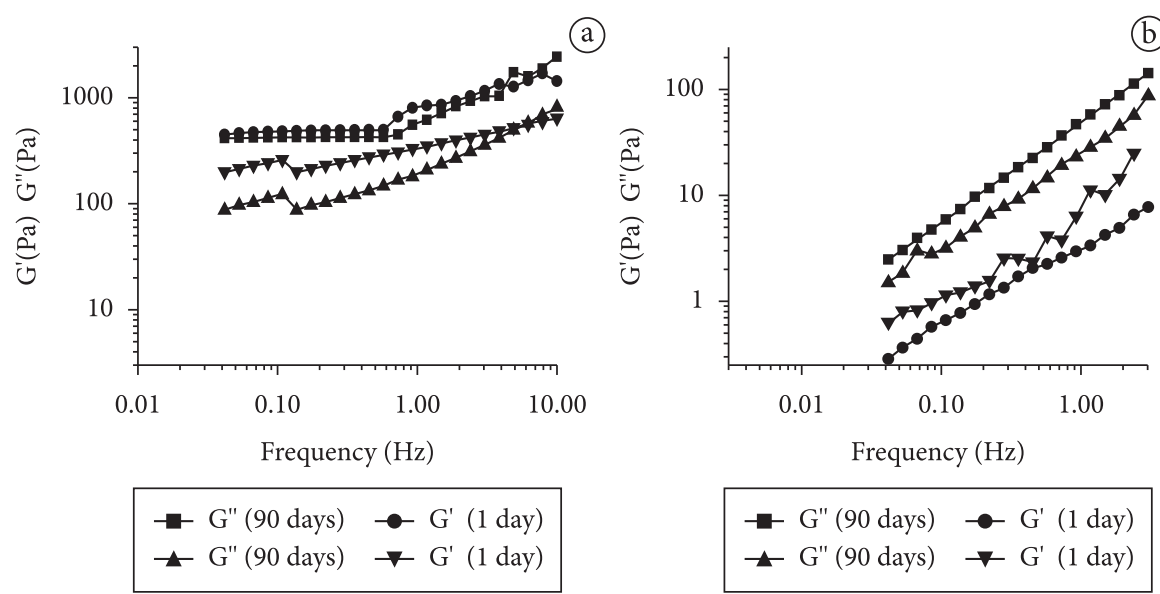

(b)

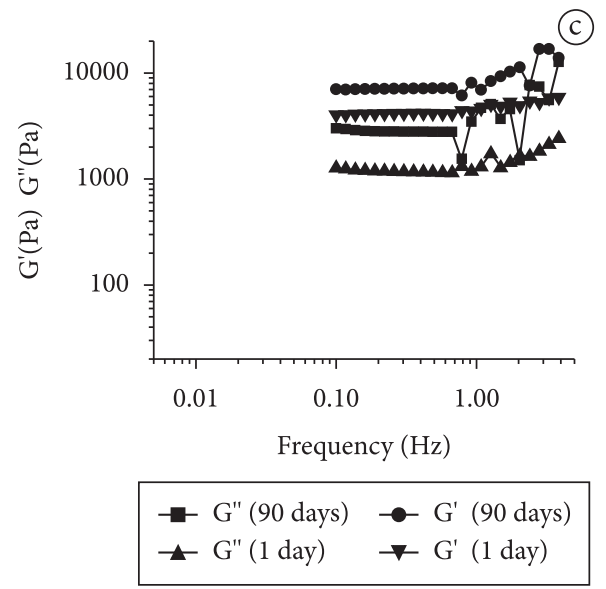

Figure 1. Frequency sweep for a) strawberry; b) passion fruit; c) and orange fruit mix.

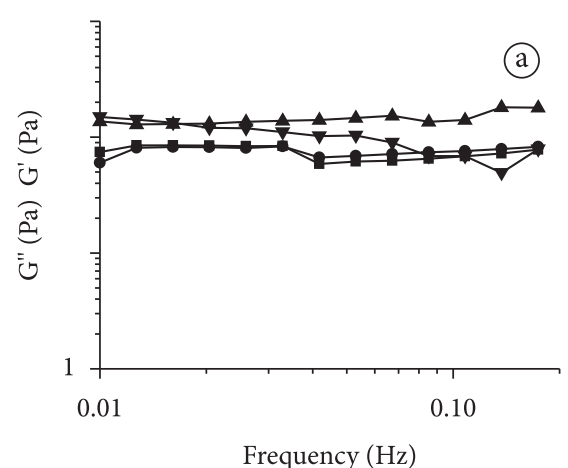

Frequency $(\mathrm{Hz})$

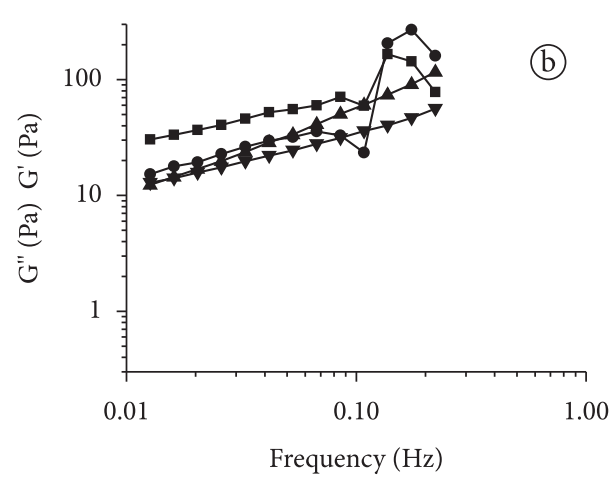

(b)

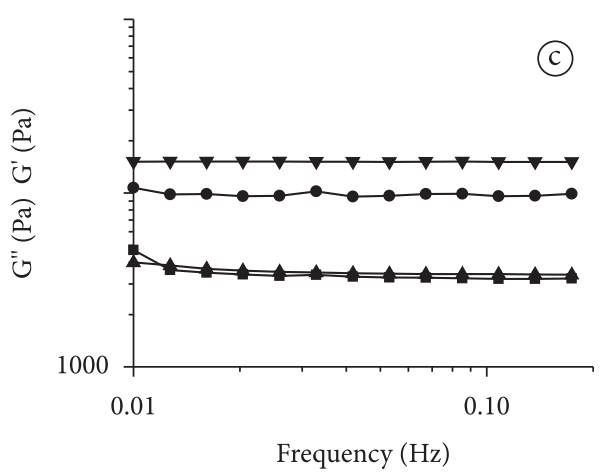

$\mathrm{G}^{\prime \prime}(90$ days $) \multimap \mathrm{G}^{\prime}(90$ days $) \multimap \mathrm{G}^{\prime \prime}(1$ day $) \multimap \mathrm{G}^{\prime}(1$ day $)$

Figure 2. Frequency sweep for a) strawberry; b) passion fruit; c) and orange fondant filling. 
fruit bases had an opposite behavior to that of strawberry and passion fruit with values of $G^{\prime}$ greater than $G^{\prime \prime}$.

Stress varied with time, but it can be said that this behavior is not due to some instability of the product during the studied time, and it is not so easy to deal with the elastic characteristics in equipment operations.

As mentioned before, the storage modulus $\left(\mathrm{G}^{\prime}\right)$ and loss $\left(G^{\prime \prime}\right)$ are strongly dependent on the particle size in suspension. Systems with small particles usually have viscous behavior that dominates over the elastic behavior (ADAMS; FRITH; STOKES, 2004). The particles volume, shape, and aggregation state in the system have an important influence on the rheological behavior of the product, either for static or dynamic systems (RICHMOND, 2002).

The results obtained for the rotational tests were presented in Figures 3 and 4. For all systems, it was observed an increase in shear stress and a decrease in viscosity as a function of the shear rate increase, which is characteristic of a plastic behavior.

Table 3 presents the yield values for the fruit bases. The results of first day of test and after 90 days of storage are in the same scale of magnitude showing slightly increases after the 90 days. The results show good product stability during storage.

For all mixtures, it could be observed that fondant filling had $\mathrm{G}^{\prime}<\mathrm{G}^{\prime \prime}$ during the 90 days of storage characterizing a typical viscous behavior. The obtained results also showed no significantly variation during that time but presented variation when submitted to frequencies higher than $0.1 \mathrm{~Hz}$. The product remained stable during the period of study even when submitted to small frequencies.

For all fillings, the behavior was analogue to the fruit bases suggesting that the bases had influence on the filling, and there was an increase in stress when compared to the bases. The crystallized sugar (bigger particle size than that of the refined sugar) used for the preparation of fondant sugar could have influenced this behavior (MINIFIE, 1983; MIQUELIM; BEHRENS; LANNES, 2008; ROBERTS; BARNES; CAREW, 2001).

For the passion fruit and strawberry fillings, the flow behavior and viscosity did not have significant variations during storage. Both were prepared with dehydrated fruit produced for confectionery application, and thus the particle size of the fruit bases and consequently of the filling could be controlled. The orange filling showed more variability over time; this could be due to the orange slices, resulting in a variation in particle sizes. The agglomeration as well the crystallization of the fruit particles were not the same. Although the yield value did not vary considerably, the necessary initial stress for the product flows was almost the same; the the yield value can be influenced by the different particle size. The yield value increases with the increase in the particle size present in the filling.

Both the fruit bases and fillings with high sugar content presented a plastic behavior. The yield value obtained for all samples showed that the material does not display flow when submitted to stress (Tables 2, 3 and 4) (MINIFIE, 1983; WEI; WANG; WU, 2001; SERVAIS; JONES; ROBERTS, 2002; YOUNG; KAPPEL; BLADT, 2003; RICHTER; LANNES, 2007).
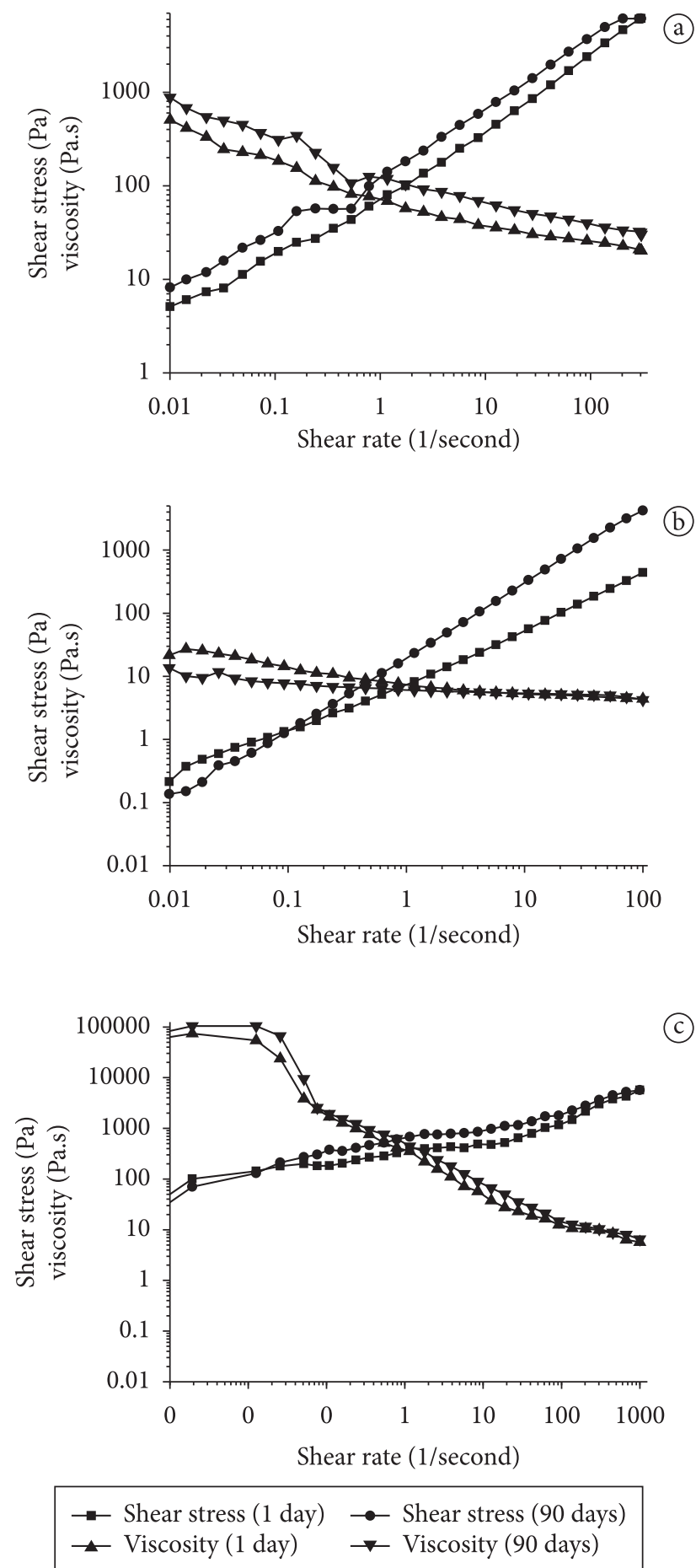

Figure 3. Flow and viscosity curves for a) strawberry; b) passion fruit; c) and orange fruit mix.

Table 3. Yield value of the fruit mixes.

\begin{tabular}{cccc}
\hline Yield value $(\mathrm{Pa})$ & \multicolumn{3}{c}{ Fruit mix } \\
\cline { 2 - 4 } & Passion fruit & Strawberry & Orange \\
\hline 1 day & 0.213 & 5.1 & 36.9 \\
90 days & 0.136 & 8.2 & 25.8 \\
\hline
\end{tabular}



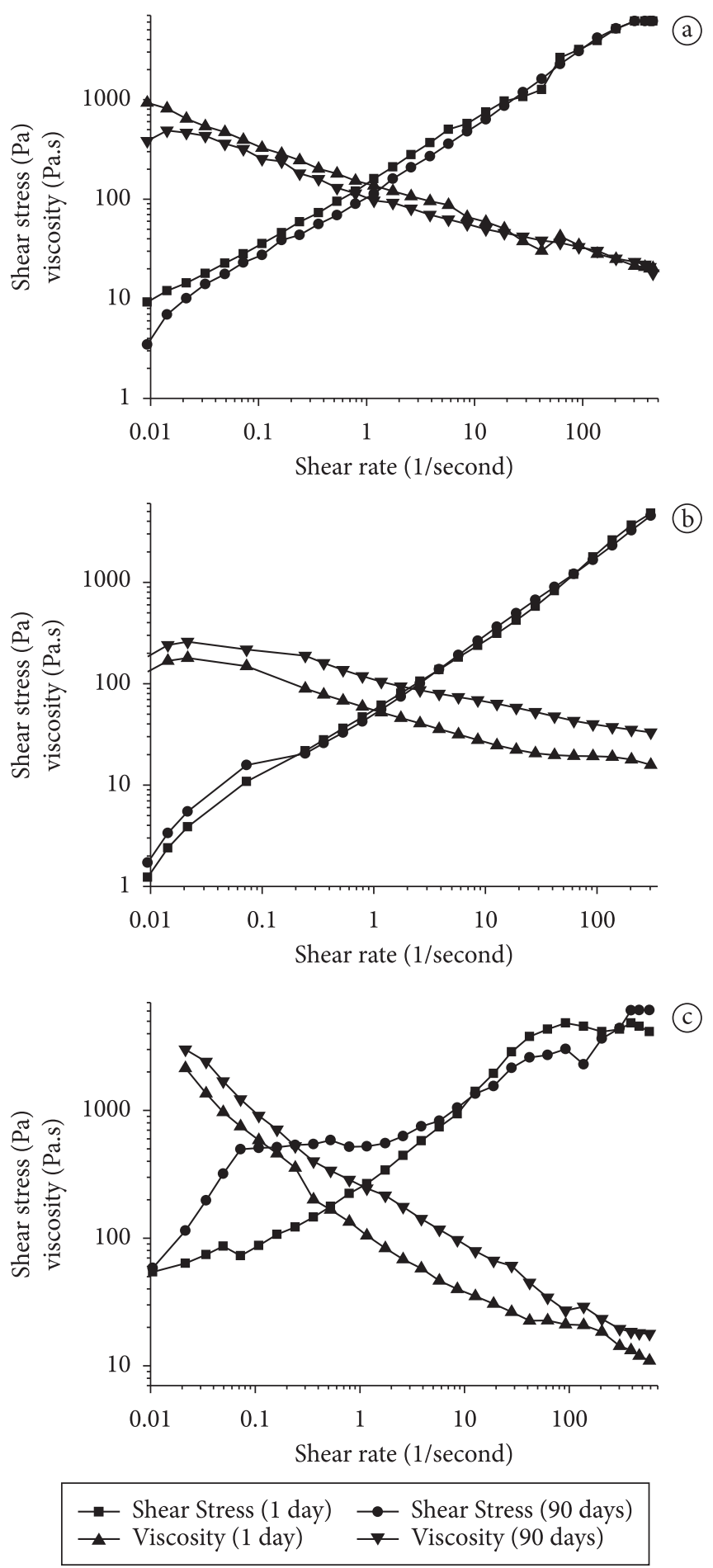

Figure 4. Flow and viscosity curves for a) strawberry; b) passion fruit; c) and orange fondant filling.

Table 4. Yield value of the fondant fillings during 90 days storage.

\begin{tabular}{cccc}
\hline Yield value $(\mathrm{Pa})$ & \multicolumn{3}{c}{ Filling } \\
\cline { 2 - 4 } & Passion fruit & Strawberry & Orange \\
\hline 1 day & 1.23 & 9.24 & 17.37 \\
90 days & 1.71 & 3.47 & 20.70 \\
\hline
\end{tabular}

\section{Conclusions}

The use of fruit bases was an efficient way to provide flavor and color to fillings reducing the need for the addition of artificial flavor and dye.

A rheological study using the oscillatory test could be used to determine the stability of fruit bases and fondant fillings during storage. Particles with different sizes in the strawberry and orange fruit, as well sugar crystallization, influenced the stability of the fillings and bases. The rotational test showed a direct correlation between particle size and yield value.

The use of fruit bases made easier the development of fillings with low cost and longer shelf life. Formulations of fruit bases had good stability and could be used by industries for new product development in different filling bases, not only for chocolate fillings. Stability during storage at room temperature should be investigated for household use.

\section{References}

ADAMS, S.; FRITH, W. J.; STOKES, J. R. Influence of particle modulus on the rheological properties of agar microgels suspensions. Journal of Rheology, v. 48, p. 1195- 1213, 2004.

ASHURST, P. R. Food flavoring. Gaithensburg: Aspen Publishers, 1999.

CORNILLON, P.; SALIM, L. C. Characterizarion of water mobility and distribution in low and intermediate moisture food systems. Magnetic Ressonance Imaging, v. 18, p. 335-341, 2000.

FERNANDEZ, P. P. et al. Effects of locust bean, xanthan and guar gums on the ice crystals of a sucrose solution frozen at high pressure. Food Hydrocolloid, v. 21, p. 507-515, 2007.

GOETZ, J.; BALZER, H.; HINRICHS, R. Characterisation of the structure and flow behaviour of model chocolate systems by means of NMR and rheology. Applied Rheology, v. 15, p. 98-111, 2005.

LEITÃO, M. F. F. Atividade de água e transformações microbiológicas de deterioração. In: SEMINÁRIO SOBRE ATIVIDADE DE ÁGUA EM ALIMENTOS. 1987. Anais... Campinas: Ital, 1987.

LENNOX, S. Gelatin alternatives in gummi confections. Manufacturing Confectioner, v. 82, p. 65-72, 2002.

LIZARRAGA, M. S. et al. Rheological behaviour of whey protein concentrate and $\lambda$-carrageenan aqueous mixtures. Food Hydrocolloids, v. 20, p. 740-748, 2006.

MINIFIE, B. W. Chocolate, cocoa and confectionery: science and technology. $2^{\text {nd }}$ ed. Westport: AVI, 1983. 735 p.

MIQUELIM, J. N.; BEHRENS, J.; LANNES, S. C. S. Analysis of Brazilian consumer preferences of filled chocolate. Ciência e Tecnologia de Alimentos, v. 28, n. 493-497, 2008.

MUNIZAGA-TABILO, G.; BARBOSA-CANOVAS, G. V. Rheology for the food industry. Journal of Food Engeenering, v. 67, p. 147-156, 2005.

NEBESNY, E. et al. Properties of sucrose-free chocolates enriched with viable lactic acid bacteria. European Food Research and Technology, v. 220, p. 358-362, 2005.

OURIEV, B. N.; URIEV, N. B. Influence of vibration on structurerheological properties of a highly concentrated suspension. Measurement Science and Technology, v. 16, p. 1691-1700, 2005.

PERESSINI, D. et al. Filled snacks production by co-extrusion-cooking. Part 3. A rheological-based method to compare filler processing properties. Journal of Food Engeneering, v. 54, p. 227-240, 2000. 
RAO, M. A. Rheology of fluid and semisolid foods: principles and applications. Gaitherburg: Aspen Publishers, 1999. 433 p. (Food Engeneering Series).

RICHMOND, W. Fudge manufacturing methods and formulas choice confections. Manufacturing Confectioner, v. 82, p. 69-91, 2002.

RICHMOND, W. Hard candy manufacturing methods and formulas. Manufacturing Confectioner, v. 84, p. 35-48, 2004.

RICHTER, M.; LANNES, S. C. S. Bombom para dietas especiais: avaliação química e sensorial. Ciência e Tecnologia de Alimentos, v. 27, p. 357-369, 2007.

ROBERTS, G. P.; BARNES, H. A.; CAREW, P. Modelling the flow behavior of very shear-thinning liquids. Chemical Engeneering Science, v. 56, p. 5617- 5623, 2001.
SERVAIS, C.; JONES, R.; ROBERTS, I. The influence of particle size distribution on the processing of food. Journal of Food Engeneering, v. 51, p. 201-208, 2002.

TORREY, M. Dehydration of fruits and vegetables. Park Ridge: Noyes Data, 1974. 286 p. (Food Technology Review, n. 13).

WEI, Y. P.; WANG, C. S.; WU, J. S. B. Flow properties of fruit fillings. Food Research International, v. 34, p. 377- 381, 2001.

YOUNG, N. W. G.; KAPPEL, G.; BLADT, T. A polyuronan blend giving novel synergistic effects and bake-stable functionally to high soluble solids fruit fillings. Food Hydrocolloids, v. 17, p. 407-418, 2003. 